\title{
Article \\ Pathological Relationship between Intracellular Superoxide Metabolism and p53 Signaling in Mice
}

\author{
Kenji Watanabe $^{1}{ }^{\oplus}$, Shuichi Shibuya ${ }^{1}$, Yusuke Ozawa ${ }^{2}$, Toshihiko Toda ${ }^{2}{ }^{\circledR}$ and Takahiko Shimizu ${ }^{1,2, *(D)}$ \\ 1 Aging Stress Response Research Project Team, National Center for Geriatrics and Gerontology, \\ Obu 474-8511, Aichi, Japan; kng-wtnb@ncgg.go.jp (K.W.); s-shibuya@ncgg.go.jp (S.S.) \\ 2 Department of Endocrinology, Hematology and Gerontology, Chiba University Graduate School of Medicine, \\ Chiba 260-8677, Chiba, Japan; ozawayusuke3@gmail.com (Y.O.); hik_toda@proteome.jp (T.T.) \\ * Correspondence: shimizut@ncgg.go.jp; Tel.: +81-0562-44-5651
}

check for updates

Citation: Watanabe, K.; Shibuya, S.; Ozawa, Y.; Toda, T.; Shimizu, T. Pathological Relationship between Intracellular Superoxide Metabolism and p53 Signaling in Mice. Int. J. Mol. Sci. 2021, 22, 3548. https://doi.org/ $10.3390 /$ ijms 22073548

Academic Editor: Vladimir Titorenko

Received: 8 February 2021

Accepted: 23 March 2021

Published: 29 March 2021

Publisher's Note: MDPI stays neutral with regard to jurisdictional claims in published maps and institutional affiliations.

Copyright: (c) 2021 by the authors. Licensee MDPI, Basel, Switzerland. This article is an open access article distributed under the terms and conditions of the Creative Commons Attribution (CC BY) license (https:// creativecommons.org/licenses/by/ $4.0 /)$.

\begin{abstract}
Intracellular superoxide dismutases (SODs) maintain tissue homeostasis via superoxide metabolism. We previously reported that intracellular reactive oxygen species (ROS), including superoxide accumulation caused by cytoplasmic SOD (SOD1) or mitochondrial SOD (SOD2) insufficiency, induced p53 activation in cells. SOD1 loss also induced several age-related pathological changes associated with increased oxidative molecules in mice. To evaluate the contribution of p53 activation for SOD1 knockout (KO) (Sod1 ${ }^{-/-}$) mice, we generated SOD1 and p53 KO (double-knockout (DKO)) mice. DKO fibroblasts showed increased cell viability with decreased apoptosis compared with Sod $1^{-/-}$fibroblasts. In vivo experiments revealed that p53 insufficiency was not a great contributor to aging-like tissue changes but accelerated tumorigenesis in Sod1 ${ }^{-/-}$mice. Furthermore, p53 loss failed to improve dilated cardiomyopathy or the survival in heart-specific SOD2 conditional KO mice. These data indicated that p53 regulated ROS-mediated apoptotic cell death and tumorigenesis but not ROS-mediated tissue degeneration in SOD-deficient models.
\end{abstract}

Keywords: superoxide dismutase (SOD); p53; superoxide; aging; apoptosis

\section{Introduction}

Age-related pathological changes are caused by several genetic and environmental factors. To analyze the age-related changes in vivo and in vitro, researchers have used several genetic and pharmacological manipulations for the induction of redox imbalance $[1,2]$. Superoxide dismutase (SOD) enzymes play a major role in the intracellular antioxidant system by catalyzing the conversion of superoxide radicals $\left(\mathrm{O}_{2}{ }^{\bullet-}\right)$ to hydrogen peroxide and $\mathrm{O}_{2}$ [3]. In mammals, copper/zinc-SOD (SOD1) exists in the cytoplasm, while manganese-SOD (SOD2) is distributed in the mitochondrial matrix to regulate intracellular redox balance in cells. Since SOD expression and activity are significantly decreased in aged osteoporotic, end-stage osteoarthritic, and Alzheimer's disease individuals [4-6], redox imbalance caused by SOD decline is considered an important mechanism underlying the induction of age-related pathological changes.

We previously reported that SOD1-deficient mice showed the accumulation of oxidative molecules and several age-related pathological changes, including macular degeneration [7,8], hemolytic anemia with splenomegaly [9], osteopenia [10,11], skin atrophy [12], skeletal muscle atrophy [13], hepatic carcinoma [14], and fatty liver [15]. In addition, SOD1-deficient phenotypes can be improved by antioxidant treatments in vivo [12,16-19]. Therefore, Sod1 $1^{-/-}$mice are a useful model for age-related tissue deregulation and intervention strategies. In addition, we previously reported that $\operatorname{Sod} 1^{-/-}$fibroblasts showed the significant presence of intracellular reactive oxygen species (ROS), including $\mathrm{O}_{2}^{\bullet-}$ accumulation accompanied by p53 upregulation, which resulted in apoptotic cell death [20]. A rescue experiment using antioxidant reagents exhibited effective suppression of p53 activation and cell death in Sod1 ${ }^{-/-}$fibroblasts [20]. These data suggest that p53 plays a 
fundamental role in SOD1 loss-related phenotypes. However, whether or not p53 activation directly regulates SOD1-deficient phenotypes in vivo and in vitro remains unclear.

In contrast to the above findings, SOD2-deficient mice showed dilated cardiomyopathy (DCM), steatosis, and metabolic acidosis, which resulted in neonatal lethality [21]. To analyze the SOD2-deficient phenotypes in adults, we generated and established tissuespecific SOD2 knockout (KO) mice [2,22]. Several tissue-specific SOD2-deficient mice showed DCM-type heart failure [23], disturbance of exercise activity [24], spongiform encephalopathy [25], bone loss [26], and cartilage degeneration [27]. Consequently, we proposed that tissue-specific SOD2 KO mice were a useful model of age-related pathological changes caused by mitochondrial dysfunction. In addition, pressure overload, hypoxic stress, and genotoxic stress-induced p53 upregulation resulted in cardiomyocyte death [28]. Heart failure such as DCM and right ventricular hypertrophy model mice also showed the accumulation of p53 and cardiomyocyte apoptosis [29-32]. Since suppression of p53 via pharmacological as well as genetic approaches ameliorated heart failure [29,33,34], p53 is considered a key molecule involved in heart failure. However, while SOD2 loss induced DCM in mice, the involvement of p53 in DCM-type heart failure caused by SOD2 loss remains unclear.

In the present study, in order to clarify the contribution of p53 to the Sod1- or Sod2deficient phenotypes in vivo, we generated two types of double-knockout (DKO) mice: Sod1 and p53 DKO mice, as well as heart-specific Sod2 and p53-deficient mice. We also discussed the influence of p53 deficiency on the phenotypes of SOD1 or heart-specific SOD2 KO mice.

\section{Results}

\section{1. p53 Insufficiency Effectively Suppressed Apoptotic Cell Death In Vitro}

Previously, we reported that the intrinsic $\mathrm{O}_{2}{ }^{\bullet-}$ accumulation by SOD1 loss promoted p53 activation and apoptotic cell death in vitro [20]. In addition, antioxidant reagents effectively attenuated Sod1-deficient phenotypes accompanied by p53 upregulation in fibroblasts and skin tissues [20]. To clarify the pathological relationship of p53 upregulation in Sod1-deficient phenotypes in mice, we generated Sod1 and p53 DKO mice. First, we performed in vitro fertilization of Sod1 KO oocytes with $p 53 \mathrm{KO}$ frozen sperm to obtain double-heterozygous mice. Next, we intercrossed double-heterozygous males and females to generate DKO mice. Unexpectedly, we obtained only a very small number of DKO mice from cross-fertilization via natural mating as well as in vitro fertilization (Table 1). These data indicated that the birth rate of DKO mice was not Mendelian.

Table 1. The genotype of births to the cross-breeding between double-heterozygous mice.

\begin{tabular}{ccccc}
\hline & & \multicolumn{3}{c}{ Sod 1 } \\
\cline { 3 - 5 } & & $+/+$ & $+/-$ & $-/-$ \\
\hline \multirow{3}{*}{$p 53$} & $+/+$ & 12 & 21 & 13 \\
\cline { 2 - 5 } & $+/-$ & 27 & 44 & 20 \\
\cline { 2 - 5 } & $-/-$ & 7 & 10 & 2 \\
\hline
\end{tabular}

Next, we assessed the efficiency of p53 loss in Sod1 ${ }^{-/-}$fibroblasts. Although Sod1 ${ }^{-/-}$ fibroblasts died within 3 days under $20 \% \mathrm{O}_{2}$ conditions, p53 loss improved the cell number decline among Sod1 ${ }^{-/-}$cells (Figure 1A). However, DKO cells showed low cell proliferation as well as significant incrementation of dihydroethidium (DHE)- and $\mathrm{CM}-\mathrm{H}_{2}$ DCFDA (DCF)-positive ROS, including $\mathrm{O}_{2}{ }^{\bullet-}$ accumulation, with values similar to those seen in Sod $1^{-/-}$cells (Figure 1B-D). Interestingly, DKO cells showed significantly fewer apoptotic cells than Sod1 $1^{-/-}$cells (Figure 1E). In contrast, $p 53^{-/-}$cells exhibited no harmful phenotypic effect, including with regard to the cell proliferation and ROS accumulation (Figure 1B-D). These data indicated that p53 impairment suppressed apoptotic cell death, which resulted in an increase in the cell survival among DKO cells. 


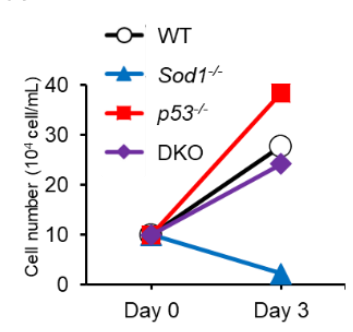

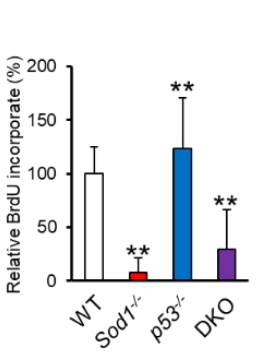

C

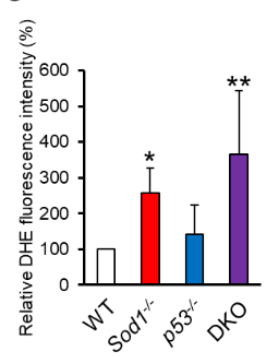

D

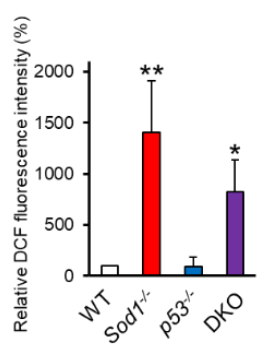

$\mathrm{E}$
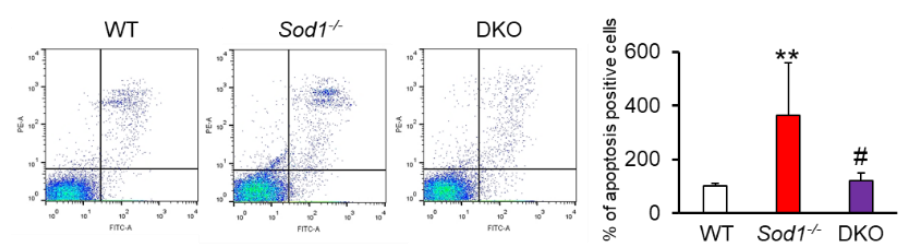

Figure 1. p53 insufficiency suppressed cytoplasmic superoxide dismutase (SOD1) loss-mediated apoptotic cell death. (A) The cell numbers of wild-type (WT); Sod1 ${ }^{-/-}, p 53^{-/-}$; and double-knockout (DKO) fibroblasts were counted at the times indicated. (B) The cell viabilities of each type of fibroblast were measured based on the incorporation of bromodeoxyuridine (BrdU) into the fibroblasts. (C,D) The intracellular superoxide accumulation was measured by flow cytometry with dihydroethidium

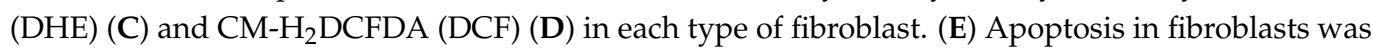
analyzed by flow cytometry with propidium iodide (PI) and annexin V. Statistical analyses were performed using a two-way analysis of variance. The error bars indicate the standard deviation of three independent experiments $(\mathrm{n}=3){ }^{*} p<0.05$, and ${ }^{* *} p<0.01$ vs. WT. $\# p<0.05$ vs. Sod1 ${ }^{-/-}$.

\section{2. p53 Loss Failed to Attenuate the SOD1-Deficient Phenotypes in Mice}

To evaluate the effect of p53 deficiency in Sod1 ${ }^{-/-}$mice, we expanded the intercrossing and analyzed organ phenotypes of DKO mice. Sod1 ${ }^{-/-}$mice revealed body weight reduction, muscle atrophy, and liver weight gain [1], but these were not significant differences compared with wild-type (WT) mice in this analysis (Figure 2A-C). SOD1 loss significantly induced skin thinning and decrease of red blood cell number but not splenomegaly (Figure 2D-F). On the other hand, $p 53^{-/-}$mice showed no significant differences in all parameters (Figure 2A-F). DKO mice showed significant reductions of muscle weight, skin thickness, and red blood cell number (Figure 2B,D,F). Interestingly, DKO mice also exhibited exacerbation of splenomegaly compared with Sod1 ${ }^{-/-}$mice (Figure 2E). Importantly, p53 haploinsufficiency also failed to improve Sod1 ${ }^{-/-}$phenotypes (Figure 2A-F). Furthermore, Sod1 $1^{+/-}, p 53^{-/-}$mice were extremely similar to WT and $p 53^{-/-}$mice (Figure 2A-F). These data indicate that p53 insufficiency did not seriously influence the organ phenotypes of Sod1 $1^{-/-}$mice.

\subsection{SOD1 and p53 DKO Mice Showed Early Tumor Progression}

About half of p53 KO mice reportedly show tumor progression by six months of age [35]. In contrast, Sod1 $\mathrm{KO}$ mice have been reported to reveal no tumor phenotypes until six months of age [14]. We therefore monitored the tumor progression phenotypes in DKO mice until four months of age. A large number of DKO mice showed remarkable spontaneous tumor progression in the appearance of discriminative by four months of age (Table 2 and Figure 3A). Whereas p53 KO mice mostly showed thymic lymphoma or sarcomas [35], DKO mice developed multifarious tumor throughout the whole body, including in the cervix, abdomen, limbs, and testis (Figure 3A,B). Importantly, Sod1 ${ }^{-/-}$, $p 53^{+/-}$as well as Sod1 $1^{+/-}, p 53^{-/-}$mice displayed no tumor progression by four months of age (Table 2), suggesting that heterozygotic loss of $p 53$ or Sod1 was sufficient to achieve the suppression of tumor development in DKO mice. These data indicated that systemic 
oxidative damage caused by complete SOD1 loss accelerated the tumor initiation and/or development in the whole body of $p 53^{-/-}$mice.
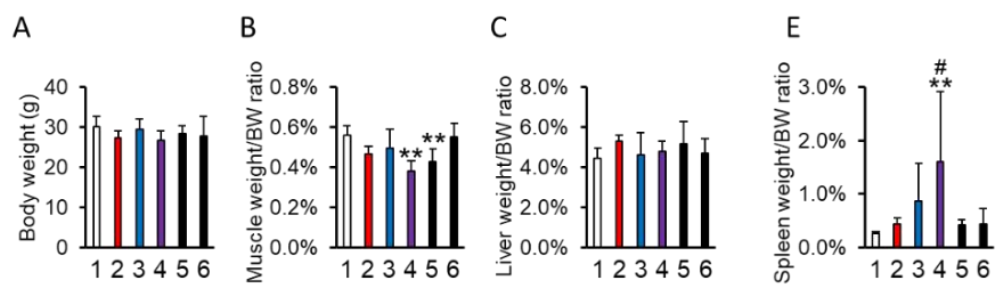

$\mathrm{F}$
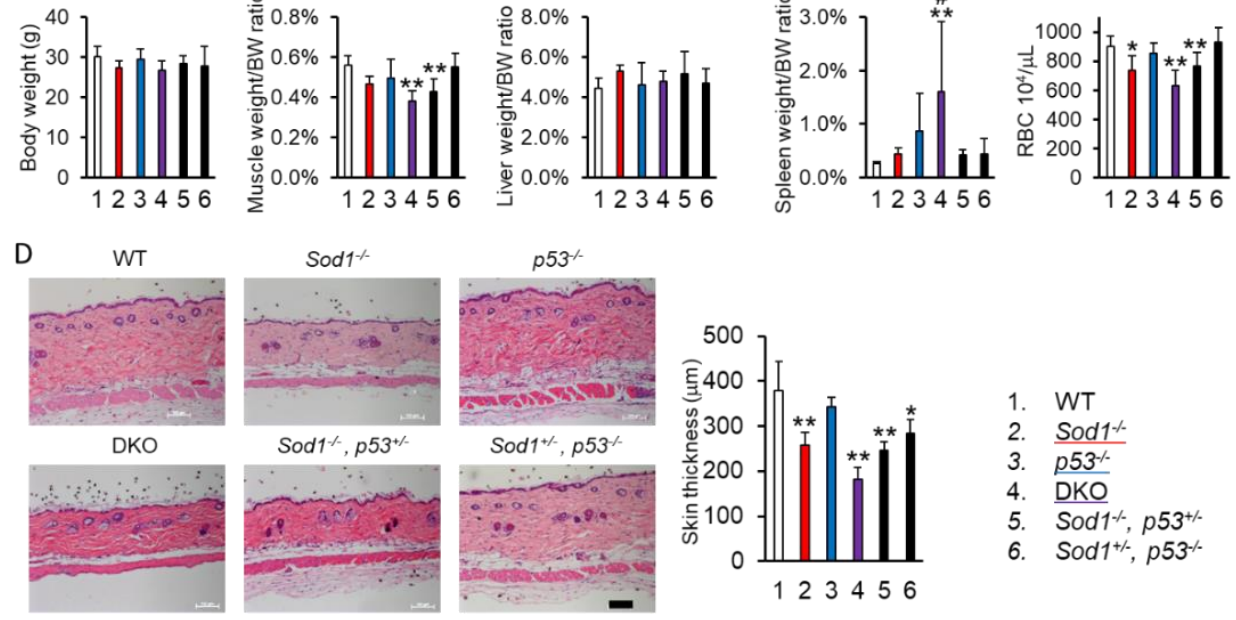

Figure 2. p53 loss had no marked effect on SOD1-decifient phenotypes in mice. (A) The body weight of each mouse (at four months of age). The genotypes for each mouse were as follows: (1) Wild-type $(n=10)$; (2) Sod $1^{-/-}(n=7)$; (3) $p 53^{-/-}$ $(n=5) ;(4)$ Sod1 $1^{-/-}, p 53^{-/-}(\mathrm{DKO}, n=5) ;(5) \operatorname{Sod1} 1^{-/-}, p 53^{+/-}(n=10) ;(6) S_{0 d 1}^{+/-}, p 53^{-/-}(n=9)$. (B) The ratio of muscle weight corrected by body weight. (C) The ratio of liver weight corrected by body weight. (D) Hematoxylin and eosin staining, the thickness of the back skin, and the skin thickness of each mouse. (E) The ratio of the spleen weight corrected by the body weight. (F) The number of red blood cells in each mouse. Statistical analyses were performed using a two-way analysis of variance. The error bars indicate the standard deviation. ${ }^{*} p<0.05 .{ }^{* *} p<0.01$ vs. WT. ${ }^{*} p<0.05$ vs. Sod1 ${ }^{-/-}$. The scale bar represents $100 \mu \mathrm{m}$.

Table 2. The number of tumor or death to each mouse until 4 months of age.

\begin{tabular}{cccc}
\hline Genotype & Number & Tumor & Death \\
\hline WT & 10 & 0 & 0 \\
Sod1 $1^{-/-}$ & 7 & 0 & 0 \\
$p 53^{-/-}$ & 6 & $1(17 \%)$ & 0 \\
DKO & 14 & $7(50 \%)$ & $2(14 \%)$ \\
Sod $1^{-/-}, p 53^{+/-}$ & 10 & 0 & 0 \\
Sod $1^{+/-}, p 53^{-/-}$ & 9 & 0 & 0 \\
\hline
\end{tabular}

A

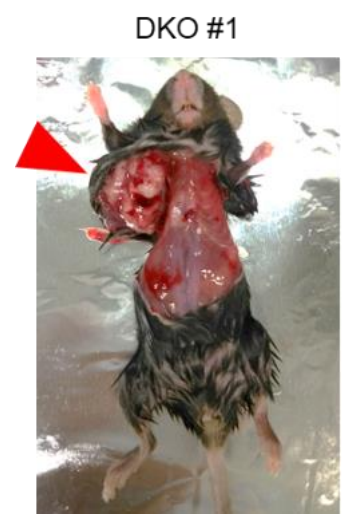

DKO \#2

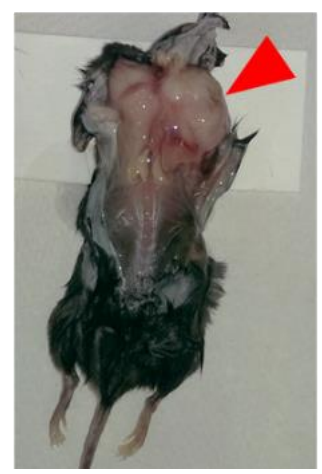

B
1. WT

3. $\frac{\text { Sod1 } 1 \%}{\mathrm{D}^{2}-}$

4. DKO

5. Sod $1 \%, p 53^{+\%}$
6. Sod $1 \%, p 53^{\%}$

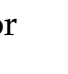




\section{4. p53 Insufficiency Had No Effect on the Heart Failure of Heart-Specific Sod2-Deficient Mice}

We previously found that heart-specific Sod2-deficient $\left(\operatorname{Sod} 2^{H / H}\right)$ mice showed a short lifespan associated with DCM [23]. Accumulating evidence has suggested that heart failure involves the p53 signaling pathway [28]. In vitro studies revealed that Sod2 loss increased mitochondrial ROS and p53 activation in mouse embryonic fibroblasts (Watanabe et al., personal communication). In this context, to clarify the contribution of p53 to heart failure in $\mathrm{Sod} 2{ }^{\mathrm{H} / \mathrm{H}}$ mice, we generated heart-specific Sod2- and $p 53$-deficient mice $\left(\mathrm{Sod} 2^{H / H}, p 53^{H / H}\right)$. Sod $2^{H / H}, p 53^{H / H}$ mice had a similarly short lifespan to $S o d 2^{H / H}$ mice (Figure 4A). Furthermore, DCM caused by heart-specific Sod2 loss was also recognized in $\operatorname{Sod} 2^{H / H}, p 53^{H / H}$ mice (Figure $4 B, C$ ). $p 53^{H / H}$ mice showed a normal lifespan and heart tissue structures with strong similarity from those of WT mice including Sod2 $f / f$ and $p 53^{f / f}$ mice (Figure 4A-C). Importantly, the pathogenesis of cardiac fibrosis was also not markedly different between Sod2 ${ }^{H / H}$ and $\mathrm{Sod} 2^{\mathrm{H} / \mathrm{H}}, p 53^{\mathrm{H} / \mathrm{H}}$ mice (Figure 4C). These data indicated that the induction and the progression of DCM phenotypes by Sod2 in mice were not influenced by the loss of the p53 molecule.

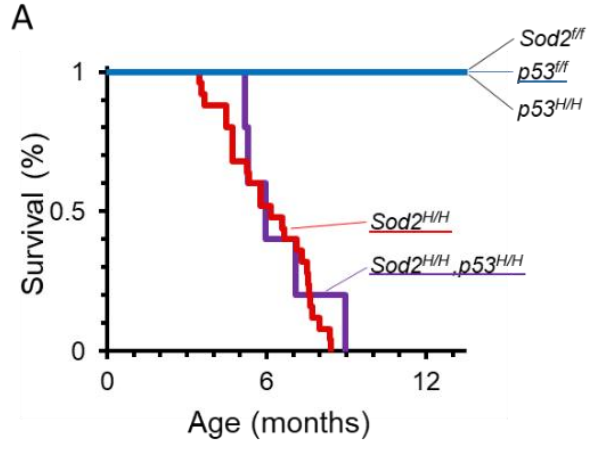

C

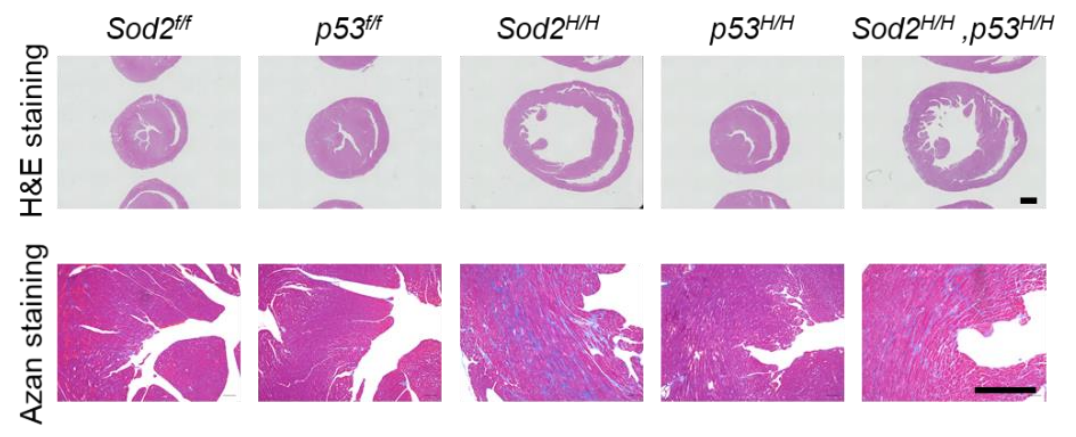

Figure 4. The mitochondrial SOD (SOD2)-deficient phenotypes were largely unaffected by p53 loss. (A) A comparison of the survival curves in each mouse. A Kaplan-Meier analysis was used to estimate the median lifespan. The numbers of individuals in each group were as follows: Sod $2^{f / f}$ $(n=8) ; p 53^{f / f}(n=8) ; \operatorname{Sod} 2^{H / H}(n=7) ; p 53^{H / H}(n=6)$; $\operatorname{Sod} 2{ }^{H / H}, p 53^{H / H}(n=11)$. (B) The ratio of heart weight corrected by body weight. (C) Hematoxylin and eosin staining as well as Azan staining of the heart of each mouse. Statistical analyses were performed using a two-way analysis of variance. The error bars indicate the standard deviation. ${ }^{* *} p<0.05$ vs. Sod $2^{f / f}$, and $\# p<0.05$ vs. $p 53^{f / f}$. The scale bars represent $1 \mathrm{~mm}((\mathbf{C})$, upper panel) and $500 \mu \mathrm{m}((\mathbf{C})$, lower panel).

\section{Discussion}

It is very well known that p53 is involved in several signaling pathways, including the DNA damage response (DDR) leading to cellular senescence induction, cell cycle arrest, DNA repair, autophagy, and cell death [36,37]. Previously, we reported that SOD1 loss induced the marked intracellular accumulation of ROS (about 40-fold) accompanied by p53 activation in vitro $[1,20]$, suggesting a close relationship between the induction of SOD1-decifient phenotypes and p53 activation in vitro. p53 regulates the cell fate, such 
as the transcriptional induction of antioxidant-, cell cycle arrest-, and apoptosis-related genes, according to the intracellular redox state [34,38]. Low levels of ROS accumulation induced p53-mediated cytoprotective property and suppressed apoptosis [39]. In addition, moderate ROS activated cell cycle checkpoint genes, which resulted in cell cycle arrest for DNA repair [40]. In contrast, excessive ROS stress was shown to lead to apoptosis [39]. Whereas $p 53$ loss remarkably increased the survival of Sod1 $1^{-/-}$fibroblasts to a point similar to that of WT cells, p53 insufficiency did not influence the intracellular ROS accumulation or cell proliferation caused by SOD1 loss (Figure 1). p53 deficiency is well known to be incapable of promoting apoptotic cell death caused by ROS in fibroblasts [41,42]. Our data also indicated that $p 53$ deficiency effectively suppressed apoptosis induction via DDR in Sod1 $1^{-/-}$cells. Therefore, DKO cells can survive despite oxidative damage under normal atmospheric conditions (Figure 1). These results indicated that p53 mainly regulated apoptotic cell death rather than cell cycle arrest when excessive intracellular ROS accumulated in Sod1 $1^{-/-}$cells.

However, an in vivo study showed that p53 did not strongly influence SOD1-deficient phenotypes (Figure 2). Since $p 53$ deficiency influenced erythrocytes turnover and eryptosis induction [43], DKO mice might show an increased rate of splenomegaly accompanied by a tendency toward decreased red blood cell numbers (Figure 1D,E). Actually, Sod1 ${ }^{-/-}$mice showed about 1.5 times the levels of systemic oxidative markers (8-isoprastane, malondialdehyde, 4-hydroxyalkenals, and 8-hydroxy-2'-deoxyguanosine (8-OHdG)) compared with WT mice $[16,18,44,45]$. In addition, SOD1-deficient tissues, such as the lacrima gland, liver, skin, and ovary, also showed relative low levels of oxidative damage $[15,16,19,45,46]$, indicating that intravital oxidative stress was moderate compared with cellular oxidative stress in vitro. Because the intravital $\mathrm{O}_{2}$ concentration remained low [47], the extent of oxidative damage caused by SOD1 loss might be too small to induce DDR-mediated apoptosis in mice. Previously, we reported that SOD1 loss activated the Forkhead box O3 (FoxO3)-metalloproteinase-2 (Mmp2) axis, resulting in skin thinness [17]. This indicated that the transcriptional factor FOXO3a and not p53 regulated skin atrophy caused by SOD1 loss.

Since SOD1 enzyme includes copper and zinc ions, SOD1 also acts as a chelator of copper and zinc ions. Sod1 deficiency might induce an increase in free copper and zinc ions in cytoplasm. Overdose of copper induced apoptotic cell death in granule cells, resulting in degeneration and neuronal loss in the central nervous system [48]. Furthermore, excessive zinc induced the disturbance of redox balance, gene expression, bone metabolism, and alternation of the p53 protein structure [49-51]. Several age-related chronic diseases also showed increased serum levels of copper and zinc ions [52,53]. In this context, ion homeostasis failure caused by SOD1 loss might induce age-related pathological changes in vivo and in vitro. Recently, several studies reported that SOD1 protein induces post-translational modifications and regulates the expression of antioxidant genes as a transcriptional factor [54]. In addition to the loss of antioxidant activity, the loss of the metal chelating ability and transcriptional function might markedly affect Sod1-deficient phenotypes. Further studies are needed to clarify the molecular mechanisms involved in Sod1-defcient phenotypes.

In contrast to the above findings, our results showed that Sod1 deficiency exacerbated tumor progression in $p 53^{-/-}$mice (Table 2). A high percentage (68\%) of Sod1 $1^{-/-}$mice revealed nodular hyperplasia or hepatocellular carcinoma by 20 months of age [14], whereas DKO mice showed the early detection of tumor formation (by 4 months) with a high probability (50\%) (Table 2 and Figure 3). Because p53 protects tumorigenesis from ROSmediated DNA damage [55], the significant increase in oxidative damage induced by SOD1 insufficiency may accelerate tumorigenesis in $p 53^{-/-}$mice. Furthermore, E2-promoter binding factor (E2F) transcriptional factor interacted with retinoblastoma susceptibility genes to regulate cellular proliferation and tumorigenesis [56,57]. Double mutant for the E2F family of transcription factors, including E2F1 and E2F2, resulted in $\gamma \mathrm{H} 2 \mathrm{AX}$ accumulation accompanied by p53 activation, which consequently caused apoptotic cell death in the 
pancreas [58]. Disruption of p53 in E2F1 and E2F2 double-knockout mice caused the suppression of apoptosis induction, which resulted in the progression of thymic lymphomas and a shortened lifespan [58]. This suggests that p53-dependent apoptosis induced by SOD1 or E2F1/E2F2 deficiencies is a key mechanism underlying tumor suppression. Accordingly, p66Shc generates hydrogen peroxide, and p66Shc loss decreases ROS production. In this context, p66Shc insufficiency significantly increased the lifespan and suppressed tumor progression in $p 53 \mathrm{KO}$ mice [59].

Many reports have shown that heart failure as age- or pathology-related phenotypes is mediated by p53 upregulation [28]. In addition, p53 suppression by pharmacological and genetic techniques ameliorates the phenotypes in heart failure models [28]. In this context, we generated $\mathrm{Sod} 2^{\mathrm{H} / \mathrm{H}}, p 53^{\mathrm{H} / \mathrm{H}}$ mice to attenuate the DCM phenotypes of $\mathrm{Sod} 2^{\mathrm{H} / \mathrm{H}}$ mice. Unexpectedly, p53 loss failed to improve the short lifespan and DCM phenotypes in Sod $2^{H / H}$ mice (Figure 4). In general, hypoxic and genotoxic stress induces cardiomyocyte apoptosis through p53 activation, resulting in heart failure $[29,30]$. However, since Sod $2^{H / H}$ mice did not show the induction of apoptotic cell death in the heart [23], p53 insufficiency may not mitigate heart failure in $S o d 2^{H / H}, p 53^{H / H}$ mice. We previously reported that antioxidant reagents, such as EUK-8, MnTBAP, manganese porphyrins, and apple procyanidins, improved DCM accompanied by a reduction in mitochondrial ROS accumulation in Sod $2^{H / H}$ mice [23,60-62]. Recently, Guo et al. reported that a loss-of-function mutation in extracellular SOD (SOD3) induced chronic kidney disease accompanied by systolic hypertension and cardiac hypertrophy in a Dahl/salt-sensitive strain of rats [63]. In addition, SOD3 KO mice also showed hypoxia-induced pulmonary vascular disease $[64,65]$. These reports suggest that not only intracellular but also extracellular ROS affect cardiac hypertrophy and cardiovascular diseases.

Taken together, our data indicate that p53 plays a minimal role in the pathogenesis of SOD1 or heart-specific SOD2 deficiency in mice. Since p53 mainly functions in apoptosis induction and tumor suppression, it has little involvement in apoptosis-independent tissue disorders, including adult $\mathrm{Sod1} 1^{-/-}$mice and $\mathrm{Sod} 2^{\mathrm{H} / \mathrm{H}}$ heart. In contrast, the suppression of apoptosis by p53 loss accelerated tumor initiation/progression in Sod1 $1^{-/-}$mice. Likewise, SOD1 deficiency accelerated tumor progression in $p 53^{-/-}$mice, indicating that apoptosis induction by p53 as well as intracellular $\mathrm{O}_{2}{ }^{--}$metabolism by SOD1 strongly contributed to tumor suppression. In conclusion, SOD1-deficient mice and tissue-specific SOD2-deficiet mice were useful model mice for an aging study without tumor progression.

\section{Materials and Methods}

\subsection{Animals}

Sod1 $1^{-/-}$mice were generated by intercrossing Sod1 $1^{+/-}$males and females (Jackson Laboratory, Bar Harbor, ME, USA). We mated Sod $1^{-/-}$mice with C57BL-p53+/ - mice (RBRC01361, RIKEN BRC, Ibaraki, Japan) [35] to generate the Sod1 and p53 DKO mice. We crossed heart-specific Sod2-deficient mice $\left(\operatorname{Sod} 2^{H / H}\right)$ [23] with Trp53 flox mice (Stock no. 008462, Jackson Laboratory) [66] to obtain heart-specific Sod2 and p53 DKO mice (Sod $2^{H / H}$, $\left.p 53^{H / H}\right)$. All of the genotypes of Sod1, p53, Cre recombination transgene, Sod2 flox, and p53 flox mice were assessed by polymerase chain reaction (PCR) using genomic DNA isolated from the tail tip, as described previously $[11,23,35,66]$. Primer sequences are given in Table S1. The animals were housed under a 12-h light/dark cycle and fed ad libitum. The experimental procedures were approved by the Animal Care and Use Committee of Chiba University and National Center for Geriatrics and Gerontology.

\subsection{Histology}

For histological morphology, skin specimens from the back tissue, heart, and tumor were dissected and fixed in a 20\% formalin neutral buffer solution (FUJIFILM Wako, Osaka, Japan) overnight while embedded in paraffin and then sectioned on a microtome at $4 \mu \mathrm{m}$ according to standard techniques. Hematoxylin and eosin staining for the skin morphology and heart as well as Azan staining for total collagen deposition were performed as described 
previously $[15,23,67]$. The thickness of the skin tissue was determined using the BZ-X Analyzer software program (Keyence, Osaka, Japan).

\subsection{Cell Culture}

The skin tissue specimens were dissected from 5-day-old neonates. The primary dermal fibroblasts were isolated by dissociation in $0.2 \%$ collagenase type 2 (Worthington Biochemical Corporation, Lakewood, NJ, USA) at $37^{\circ} \mathrm{C}$ for $60 \mathrm{~min}$. The cells were cultured in minimum essential medium Eagle, alpha modification ( $\alpha$-MEM; Life Technologies Corporation, Carlsbad, CA, USA) supplemented with $20 \%$ fetal bovine serum (FBS, Thermo Fisher Scientific, Waltham, MA, USA), $100 \mathrm{unit} / \mathrm{mL}$ penicillin, and $0.1 \mathrm{mg} / \mathrm{mL}$ streptomycin at $37^{\circ} \mathrm{C}$ in a humidified incubator (ASTEC, Fukuoka, Japan) with $5 \% \mathrm{CO}_{2}$ and $1 \% \mathrm{O}_{2}$ to expand and maintain Sod1 $1^{-/-}$fibroblasts. During experiments, the cells were cultured under $20 \% \mathrm{O}_{2}$ conditions. Cell viability was measured by the cell proliferation enzymelinked immunosorbent assay bromodeoxyuridine (BrdU; Roche Diagnostics K.K., Basel, Switzerland) according to the manufacturer's instructions. The relative BrdU incorporate values were calculated by a triplicate analysis.

\subsection{Flow Cytometry}

The accumulation of intracellular ROS was detected using DHE and DCF (Life Technologies Corporation). The cells were incubated with $10 \mu \mathrm{M}$ DHE or $10 \mu \mathrm{M}$ DCF for $30 \mathrm{~min}$ at $37^{\circ} \mathrm{C}$. Following incubation, the cells were trypsinized and resuspended in phosphate-buffered saline. Apoptosis was measured using a fluorescein isothiocyanate (FITC) Annexin V Apoptosis Detection Kit I (BD Biosciences, San Diego, CA, USA) according to the manufacturer's instructions. The fluorescence intensities were assessed using a flow cytometer (BD FACSCanto II; BD Biosciences, San Diego, CA, USA).

\subsection{Statistical Analyses}

Statistical evaluations were performed using a two-way analysis of variance with the GraphPad Prism9 software program (GraphPad Software, San Diego, CA, USA). Differences between the data were considered to be significant when the $p$-values were less than 0.05 . The data are represented as the means \pm the standard deviation (SD).

Supplementary Materials: The following are available online at https:/ /www.mdpi.com/article/10 .3390/ijms22073548/s1: Table S1: List of primers used for genotyping.

Author Contributions: K.W. and T.S. designed the research. K.W. and T.S. wrote the manuscript. K.W., S.S., Y.O. and T.T. performed research. K.W. analyzed the data. K.W., S.S., Y.O., T.T. and T.S. discussed the hypothesis and interpreted the data. K.W. and T.S. edited the article. T.S. coordinated and directed the project. All authors have read and agreed to the published version of the manuscript.

Funding: This work was supported by Research fund of Mitsukoshi Health and Welfare Foundation (T. Shimizu) and a grant-in-aid (T. Shimizu) from the Ministry of Education, Science, Culture, Sports.

Institutional Review Board Statement: All animal experiments were performed according to the guidelines for animal experiments of Animal Care and Use Committee of Chiba University (Approval ID. A28-248, G26-58).and National Center for Geriatrics and Gerontology (Approval ID. A2-28, G2-28).

Informed Consent Statement: Not applicable for studies not involving humans.

Acknowledgments: We thank Tomoaki Tanaka (Department of Molecular Diagnosis, Graduate School of Medicine, Chiba University) for providing Trp53 flox mice, and Isao Masuda, Hirohumi Koyama, and Naotaka Izuo (Department of Endocrinology, Hematology and Gerontology, Chiba University Graduate School of Medicine, Chiba, Japan) for their helpful discussion.

Conflicts of Interest: The authors declare no conflict of interest. 


$\begin{array}{ll}\text { Abbreviations } & \\ \alpha \text {-MEM } & \text { Minimum Essential Medium Eagle, Alpha Modification } \\ \text { BrdU } & \text { 5-bromo-2'-deoxyuridine } \\ \text { DCF } & \begin{array}{l}\text { 5-(and-6)-chloromethyl-2' } \text {, }^{\prime} \text {-dichlorodihydrofluorescein diacetate, } \\ \text { acetyl ester, CM- } \mathrm{H}_{2} \text { DCFDA }\end{array} \\ \text { DCM } & \text { dilated cardiomyopathy } \\ \text { DDR } & \text { DNA damage response } \\ \text { DHE } & \text { dihydroethidium } \\ \text { DKO } & \text { double-knockout } \\ \text { E2F } & \text { E2-promoter binding factor } \\ \text { FITC } & \text { Fluorescein isothiocyanate } \\ \text { FoxO3 } & \text { Forkhead box O3 } \\ \text { Mmp } & \text { Metalloproteinase } \\ \text { NQO } & \text { NAD(P)H: quinone oxidoreductase } \\ \text { PCR } & \text { Polymerase chain reaction } \\ \text { ROS } & \text { Reactive oxygen species } \\ \text { SOD } & \text { Superoxide dismutase } \\ \text { TFAM } & \text { Mitochondrial transcription factor A } \\ \text { TLR4 } & \text { Toll like receptor 4 } \\ \text { 8-OHdG } & \text { 8-hydroxy-2'-deoxyguanosine }\end{array}$

\section{References}

1. Watanabe, K.; Shibuya, S.; Ozawa, Y.; Nojiri, H.; Izuo, N.; Yokote, K.; Shimizu, T. Superoxide dismutase 1 loss disturbs intracellular redox signaling, resulting in global age-related pathological changes. Biomed. Res. Int. 2014, 2014, 140165. [CrossRef] [PubMed]

2. Shimizu, T.; Nojiri, H.; Kawakami, S.; Uchiyama, S.; Shirasawa, T. Model mice for tissue-specific deletion of the manganese superoxide dismutase gene. Geriat. Gerontol. Int. 2010, 10 (Suppl. 1), S70-S79. [CrossRef] [PubMed]

3. Okado-Matsumoto, A.; Fridovich, I. Subcellular distribution of superoxide dismutases (SOD) in rat liver: $\mathrm{Cu}, \mathrm{Zn}-\mathrm{SOD}$ in mitochondria. J. Biol. Chem. 2001, 276, 38388-38393. [CrossRef]

4. Maggio, D.; Barabani, M.; Pierandrei, M.; Polidori, M.C.; Catani, M.; Mecocci, P.; Senin, U.; Pacifici, R.; Cherubini, A. Marked decrease in plasma antioxidants in aged osteoporotic women: Results of a cross-sectional study. J. Clin. Endocrinol. Metab. 2003, 88, 1523-1527. [CrossRef] [PubMed]

5. Cao, K.; Dong, Y.T.; Xiang, J.; Xu, Y.; Hong, W.; Song, H.; Guan, Z.Z. Reduced expression of SIRT1 and SOD-1 and the correlation between these levels in various regions of the brains of patients with Alzheimer's disease. J. Clin. Pathol. 2018, 71, 1090-1099. [CrossRef] [PubMed]

6. Koike, M.; Nojiri, H.; Kanazawa, H.; Yamaguchi, H.; Miyagawa, K.; Nagura, N.; Banno, S.; Iwase, Y.; Kurosawa, H.; Kaneko, K. Superoxide dismutase activity is significantly lower in end-stage osteoarthritic cartilage than non-osteoarthritic cartilage. PLoS ONE 2018, 13, e0203944. [CrossRef]

7. Imamura, Y.; Noda, S.; Hashizume, K.; Shinoda, K.; Yamaguchi, M.; Uchiyama, S.; Shimizu, T.; Mizushima, Y.; Shirasawa, T.; Tsubota, K. Drusen, choroidal neovascularization, and retinal pigment epithelium dysfunction in SOD1-deficient mice: A model of age-related macular degeneration. Proc. Natl. Acad. Sci. USA 2006, 103, 11282-11287. [CrossRef]

8. Hashizume, K.; Hirasawa, M.; Imamura, Y.; Noda, S.; Shimizu, T.; Shinoda, K.; Kurihara, T.; Noda, K.; Ozawa, Y.; Ishida, S.; et al. Retinal dysfunction and progressive retinal cell death in SOD1-deficient mice. Am. J. Pathol. 2008, 172, 1325-1331. [CrossRef]

9. Iuchi, Y.; Okada, F.; Onuma, K.; Onoda, T.; Asao, H.; Kobayashi, M.; Fujii, J. Elevated oxidative stress in erythrocytes due to a SOD1 deficiency causes anaemia and triggers autoantibody production. Biochem. J. 2007, 402, 219-227. [CrossRef]

10. Nojiri, H.; Saita, Y.; Morikawa, D.; Kobayashi, K.; Tsuda, C.; Miyazaki, T.; Saito, M.; Marumo, K.; Yonezawa, I.; Kaneko, K.; et al. Cytoplasmic superoxide causes bone fragility owing to low-turnover osteoporosis and impaired collagen cross-linking. J. Bone Miner. Res. 2011, 26, 2682-2694. [CrossRef]

11. Morikawa, D.; Nojiri, H.; Saita, Y.; Kobayashi, K.; Watanabe, K.; Ozawa, Y.; Koike, M.; Asou, Y.; Takaku, T.; Kaneko, K.; et al. Cytoplasmic reactive oxygen species and SOD1 regulate bone mass during mechanical unloading. J. Bone Miner. Res. 2013, 28, 2368-2380. [CrossRef]

12. Shibuya, S.; Kinoshita, K.; Shimizu, T. Protective effects of vitamin C derivatives on skin atrophy caused by Sod1 deficiency. In Handbook of Diet, Nutrition and the Skin; Wageningen Academic: Gelderland, The Netherlands, 2012.

13. Muller, F.L.; Song, W.; Liu, Y.; Chaudhuri, A.; Pieke-Dahl, S.; Strong, R.; Huang, T.T.; Epstein, C.J.; Roberts, L.J., 2nd; Csete, M.; et al. Absence of $\mathrm{CuZn}$ superoxide dismutase leads to elevated oxidative stress and acceleration of age-dependent skeletal muscle atrophy. Free Radic. Biol. Med. 2006, 40, 1993-2004. [CrossRef]

14. Elchuri, S.; Oberley, T.D.; Qi, W.; Eisenstein, R.S.; Jackson Roberts, L.; Van Remmen, H.; Epstein, C.J.; Huang, T.T. CuZnSOD deficiency leads to persistent and widespread oxidative damage and hepatocarcinogenesis later in life. Oncogene 2005, 24, 367-380. [CrossRef] 
15. Uchiyama, S.; Shimizu, T.; Shirasawa, T. CuZn-SOD deficiency causes ApoB degradation and induces hepatic lipid accumulation by impaired lipoprotein secretion in mice. J. Biol. Chem. 2006, 281, 31713-31719. [CrossRef]

16. Watanabe, K.; Shibuya, S.; Ozawa, Y.; Izuo, N.; Shimizu, T. Resveratrol Derivative-Rich Melinjo Seed Extract Attenuates Skin Atrophy in Sod1-Deficient Mice. Oxid. Med. Cell Longev. 2015, 2015, 391075. [CrossRef] [PubMed]

17. Kim, J.; Toda, T.; Watanabe, K.; Shibuya, S.; Ozawa, Y.; Izuo, N.; Cho, S.; Seo, D.B.; Yokote, K.; Shimizu, T. Syringaresinol Reverses Age-Related Skin Atrophy by Suppressing FoxO3a-Mediated Matrix Metalloproteinase-2 Activation in Copper/Zinc Superoxide Dismutase-Deficient Mice. J. Investig. Dermatol. 2019, 139, 648-655. [CrossRef]

18. Shibuya, S.; Ozawa, Y.; Toda, T.; Watanabe, K.; Tometsuka, C.; Ogura, T.; Koyama, Y.; Shimizu, T. Collagen peptide and vitamin C additively attenuate age-related skin atrophy in Sod1-deficient mice. Biosci. Biotechnol. Biochem. 2014, 78, 1212-1220. [CrossRef] [PubMed]

19. Shibuya, S.; Ozawa, Y.; Watanabe, K.; Izuo, N.; Toda, T.; Yokote, K.; Shimizu, T. Palladium and platinum nanoparticles attenuate aging-like skin atrophy via antioxidant activity in mice. PLoS ONE 2014, 9, e109288. [CrossRef]

20. Watanabe, K.; Shibuya, S.; Koyama, H.; Ozawa, Y.; Toda, T.; Yokote, K.; Shimizu, T. Sod1 loss induces intrinsic superoxide accumulation leading to p53-mediated growth arrest and apoptosis. Int. J. Mol. Sci. 2013, 14, 10998-11010. [CrossRef] [PubMed]

21. Li, Y.; Huang, T.T.; Carlson, E.J.; Melov, S.; Ursell, P.C.; Olson, J.L.; Noble, L.J.; Yoshimura, M.P.; Berger, C.; Chan, P.H.; et al. Dilated cardiomyopathy and neonatal lethality in mutant mice lacking manganese superoxide dismutase. Nat. Genet. 1995, 11, 376-381. [CrossRef]

22. Ikegami, T.; Suzuki, Y.; Shimizu, T.; Isono, K.; Koseki, H.; Shirasawa, T. Model mice for tissue-specific deletion of the manganese superoxide dismutase (MnSOD) gene. Biochem. Biophys. Res. Commun. 2002, 296, 729-736. [CrossRef]

23. Nojiri, H.; Shimizu, T.; Funakoshi, M.; Yamaguchi, O.; Zhou, H.; Kawakami, S.; Ohta, Y.; Sami, M.; Tachibana, T.; Ishikawa, H.; et al. Oxidative stress causes heart failure with impaired mitochondrial respiration. J. Biol. Chem. 2006, 281, 33789-33801. [CrossRef]

24. Kuwahara, H.; Horie, T.; Ishikawa, S.; Tsuda, C.; Kawakami, S.; Noda, Y.; Kaneko, T.; Tahara, S.; Tachibana, T.; Okabe, M.; et al. Oxidative stress in skeletal muscle causes severe disturbance of exercise activity without muscle atrophy. Free Radic. Biol. Med. 2010, 48, 1252-1262. [CrossRef]

25. Izuo, N.; Nojiri, H.; Uchiyama, S.; Noda, Y.; Kawakami, S.; Kojima, S.; Sasaki, T.; Shirasawa, T.; Shimizu, T. Brain-Specific Superoxide Dismutase 2 Deficiency Causes Perinatal Death with Spongiform Encephalopathy in Mice. Oxid. Med. Cell Longev. 2015, 2015, 238914. [CrossRef]

26. Kobayashi, K.; Nojiri, H.; Saita, Y.; Morikawa, D.; Ozawa, Y.; Watanabe, K.; Koike, M.; Asou, Y.; Shirasawa, T.; Yokote, K.; et al. Mitochondrial superoxide in osteocytes perturbs canalicular networks in the setting of age-related osteoporosis. Sci. Rep. 2015, 5, 9148. [CrossRef]

27. Koike, M.; Nojiri, H.; Ozawa, Y.; Watanabe, K.; Muramatsu, Y.; Kaneko, H.; Morikawa, D.; Kobayashi, K.; Saita, Y.; Sasho, T.; et al. Mechanical overloading causes mitochondrial superoxide and SOD2 imbalance in chondrocytes resulting in cartilage degeneration. Sci. Rep. 2015, 5, 11722. [CrossRef]

28. Morita, H.; Komuro, I. Heart Failure as an Aging-Related Phenotype. Int. Heart J. 2018, 59, 6-13. [CrossRef] [PubMed]

29. Sano, M.; Minamino, T.; Toko, H.; Miyauchi, H.; Orimo, M.; Qin, Y.; Akazawa, H.; Tateno, K.; Kayama, Y.; Harada, M.; et al. p53-induced inhibition of Hif-1 causes cardiac dysfunction during pressure overload. Nature 2007, 446, 444-448. [CrossRef] [PubMed]

30. Naito, A.T.; Okada, S.; Minamino, T.; Iwanaga, K.; Liu, M.L.; Sumida, T.; Nomura, S.; Sahara, N.; Mizoroki, T.; Takashima, A.; et al. Promotion of CHIP-mediated p53 degradation protects the heart from ischemic injury. Circ. Res. 2010, 106, 1692-1702. [CrossRef] [PubMed]

31. Sun, A.; Zou, Y.; Wang, P.; Xu, D.; Gong, H.; Wang, S.; Qin, Y.; Zhang, P.; Chen, Y.; Harada, M.; et al. Mitochondrial aldehyde dehydrogenase 2 plays protective roles in heart failure after myocardial infarction via suppression of the cytosolic JNK/p53 pathway in mice. J. Am. Heart Assoc. 2014, 3, e000779. [CrossRef]

32. Veeroju, S.; Mamazhakypov, A.; Rai, N.; Kojonazarov, B.; Nadeau, V.; Breuils-Bonnet, S.; Li, L.; Weissmann, N.; Rohrbach, S.; Provencher, S.; et al. Effect of p53 activation on experimental right ventricular hypertrophy. PLoS ONE 2020, 15, e0234872. [CrossRef]

33. Hoshino, A.; Mita, Y.; Okawa, Y.; Ariyoshi, M.; Iwai-Kanai, E.; Ueyama, T.; Ikeda, K.; Ogata, T.; Matoba, S. Cytosolic p53 inhibits Parkin-mediated mitophagy and promotes mitochondrial dysfunction in the mouse heart. Nat. Commun. 2013, 4, 2308. [CrossRef] [PubMed]

34. Gu, J.; Wang, S.; Guo, H.; Tan, Y.; Liang, Y.; Feng, A.; Liu, Q.; Damodaran, C.; Zhang, Z.; Keller, B.B.; et al. Inhibition of p53 prevents diabetic cardiomyopathy by preventing early-stage apoptosis and cell senescence, reduced glycolysis, and impaired angiogenesis. Cell Death Dis. 2018, 9, 82. [CrossRef] [PubMed]

35. Tsukada, T.; Tomooka, Y.; Takai, S.; Ueda, Y.; Nishikawa, S.; Yagi, T.; Tokunaga, T.; Takeda, N.; Suda, Y.; Abe, S.; et al. Enhanced proliferative potential in culture of cells from p53-deficient mice. Oncogene 1993, 8, 3313-3322.

36. Ou, H.L.; Schumacher, B. DNA damage responses and p53 in the aging process. Blood 2018, 131, 488-495. [CrossRef] [PubMed]

37. Czarny, P.; Pawlowska, E.; Bialkowska-Warzecha, J.; Kaarniranta, K.; Blasiak, J. Autophagy in DNA damage response. Int. J. Mol. Sci. 2015, 16, 2641-2662. [CrossRef] 
38. Simabuco, F.M.; Morale, M.G.; Pavan, I.C.B.; Morelli, A.P.; Silva, F.R.; Tamura, R.E. p53 and metabolism: From mechanism to therapeutics. Oncotarget 2018, 9, 23780-23823. [CrossRef]

39. Lee, B.W.L.; Ghode, P.; Ong, D.S.T. Redox regulation of cell state and fate. Redox Biol. 2019, 25, 101056. [CrossRef]

40. Storr, S.J.; Woolston, C.M.; Zhang, Y.; Martin, S.G. Redox environment, free radical, and oxidative DNA damage. Antioxid. Redox Signal. 2013, 18, 2399-2408. [CrossRef]

41. Montero, J.; Dutta, C.; van Bodegom, D.; Weinstock, D.; Letai, A. p53 regulates a non-apoptotic death induced by ROS. Cell Death Differ. 2013, 20, 1465-1474. [CrossRef]

42. McCurrach, M.E.; Connor, T.M.; Knudson, C.M.; Korsmeyer, S.J.; Lowe, S.W. bax-deficiency promotes drug resistance and oncogenic transformation by attenuating p53-dependent apoptosis. Proc. Natl. Acad. Sci. USA 1997, 94, 2345-2349. [CrossRef] [PubMed]

43. Bissinger, R.; Lang, E.; Gonzalez-Menendez, I.; Quintanilla-Martinez, L.; Ghashghaeinia, M.; Pelzl, L.; Sukkar, B.; Bhuyan, A.A.M.; Salker, M.S.; Singh, Y.; et al. Genetic deficiency of the tumor suppressor protein p53 influences erythrocyte survival. Apoptosis 2018, 23, 641-650. [CrossRef] [PubMed]

44. Murakami, K.; Murata, N.; Noda, Y.; Tahara, S.; Kaneko, T.; Kinoshita, N.; Hatsuta, H.; Murayama, S.; Barnham, K.J.; Irie, K.; et al. SOD1 (copper/zinc superoxide dismutase) deficiency drives amyloid $\beta$ protein oligomerization and memory loss in mouse model of Alzheimer disease. J. Biol. Chem. 2011, 286, 44557-44568. [CrossRef] [PubMed]

45. Kojima, T.; Wakamatsu, T.H.; Dogru, M.; Ogawa, Y.; Igarashi, A.; Ibrahim, O.M.; Inaba, T.; Shimizu, T.; Noda, S.; Obata, H.; et al Age-related dysfunction of the lacrimal gland and oxidative stress: Evidence from the Cu,Zn-superoxide dismutase-1 (Sod1) knockout mice. Am. J. Pathol. 2012, 180, 1879-1896. [CrossRef]

46. Noda, Y.; Ota, K.; Shirasawa, T.; Shimizu, T. Copper/zinc superoxide dismutase insufficiency impairs progesterone secretion and fertility in female mice. Biol. Reprod. 2012, 86, 1-8. [CrossRef]

47. Spencer, J.A.; Ferraro, F.; Roussakis, E.; Klein, A.; Wu, J.; Runnels, J.M.; Zaher, W.; Mortensen, L.J.; Alt, C.; Turcotte, R.; et al. Direct measurement of local oxygen concentration in the bone marrow of live animals. Nature 2014, 508, 269-273. [CrossRef]

48. Akdogan, I.; Adiguzel, E.; Turgut, G.; Genc, O.; Tufan, A.C. Granule cell apoptosis induced by overdose copper and ethanol is counterbalanced by co-induced cellular proliferation in rat dentate gyrus. Tohoku J. Exp. Med. 2005, 205, 171-178. [CrossRef]

49. Rouphael, Y.; Colla, G.; Bernardo, L.; Kane, D.; Trevisan, M.; Lucini, L. Zinc Excess Triggered Polyamines Accumulation in Lettuce Root Metabolome, As Compared to Osmotic Stress under High Salinity. Front. Plant. Sci. 2016, 7, 842. [CrossRef]

50. Sun, J.Y.; Wang, J.F.; Zi, N.T.; Jing, M.Y.; Weng, X.Y. Effects of zinc supplementation and deficiency on bone metabolism and related gene expression in rat. Biol. Trace Elem. Res. 2011, 143, 394-402. [CrossRef]

51. Formigari, A.; Gregianin, E.; Irato, P. The effect of zinc and the role of p53 in copper-induced cellular stress responses. J. Appl. Toxicol. 2013, 33, 527-536. [CrossRef]

52. Malavolta, M.; Piacenza, F.; Basso, A.; Giacconi, R.; Costarelli, L.; Mocchegiani, E. Serum copper to zinc ratio: Relationship with aging and health status. Mech. Ageing Dev. 2015, 151, 93-100. [CrossRef]

53. Mezzetti, A.; Pierdomenico, S.D.; Costantini, F.; Romano, F.; De Cesare, D.; Cuccurullo, F.; Imbastaro, T.; Riario-Sforza, G.; Di Giacomo, F.; Zuliani, G.; et al. Copper/zinc ratio and systemic oxidant load: Effect of aging and aging-related degenerative diseases. Free Radic. Biol. Med. 1998, 25, 676-681. [CrossRef]

54. Eleutherio, E.C.A.; Silva Magalhaes, R.S.; de Araujo Brasil, A.; Monteiro Neto, J.R.; de Holanda Paranhos, L. SOD1, more than just an antioxidant. Arch. Biochem. Biophys. 2021, 697, 108701. [CrossRef] [PubMed]

55. Chen, X.; Ko, L.J.; Jayaraman, L.; Prives, C. p53 levels, functional domains, and DNA damage determine the extent of the apoptotic response of tumor cells. Genes Dev. 1996, 10, 2438-2451. [CrossRef] [PubMed]

56. Chellappan, S.P.; Hiebert, S.; Mudryj, M.; Horowitz, J.M.; Nevins, J.R. The E2F transcription factor is a cellular target for the RB protein. Cell 1991, 65, 1053-1061. [CrossRef]

57. Johnson, J.; Thijssen, B.; McDermott, U.; Garnett, M.; Wessels, L.F.; Bernards, R. Targeting the RB-E2F pathway in breast cancer. Oncogene 2016, 35, 4829-4835. [CrossRef]

58. Iglesias-Ara, A.; Zenarruzabeitia, O.; Buelta, L.; Merino, J.; Zubiaga, A.M. E2F1 and E2F2 prevent replicative stress and subsequent p53-dependent organ involution. Cell Death Differ. 2015, 22, 1577-1589. [CrossRef]

59. Beltrami, E.; Valtorta, S.; Moresco, R.; Marcu, R.; Belloli, S.; Fassina, A.; Fazio, F.; Pelicci, P.; Giorgio, M. The p53-p66Shc apoptotic pathway is dispensable for tumor suppression whereas the p66Shc-generated oxidative stress initiates tumorigenesis. Curr. Pharm. Des. 2013, 19, 2708-2714. [CrossRef]

60. Sunagawa, T.; Shimizu, T.; Matsumoto, A.; Tagashira, M.; Kanda, T.; Shirasawa, T.; Nakaya, H. Cardiac electrophysiological alterations in heart/muscle-specific manganese-superoxide dismutase-deficient mice: Prevention by a dietary antioxidant polyphenol. Biomed. Res. Int. 2014, 2014, 704291. [CrossRef] [PubMed]

61. Hayakawa, N.; Asayama, S.; Noda, Y.; Shimizu, T.; Kawakami, H. Pharmaceutical effect of manganese porphyrins on manganese superoxide dismutase deficient mice. Mol. Pharm. 2012, 9, 2956-2959. [CrossRef]

62. Kawakami, S.; Matsuda, A.; Sunagawa, T.; Noda, Y.; Kaneko, T.; Tahara, S.; Hiraumi, Y.; Adachi, S.; Matsui, H.; Ando, K.; et al. Antioxidant, EUK-8, prevents murine dilated cardiomyopathy. Circ. J. 2009, 73, 2125-2134. [CrossRef] [PubMed]

63. Guo, H.; Xu, D.; Kuroki, M.; Lu, Z.; Xu, X.; Geurts, A.; Osborn, J.W.; Chen, Y. Kidney failure, arterial hypertension and left ventricular hypertrophy in rats with loss of function mutation of SOD3. Free Radic. Biol. Med. 2020, 152, 787-796. [CrossRef] [PubMed] 
64. Arcucci, A.; Ruocco, M.R.; Albano, F.; Granato, G.; Romano, V.; Corso, G.; Bancone, C.; De Vendittis, E.; Della Corte, A.; Montagnani, S. Analysis of extracellular superoxide dismutase and Akt in ascending aortic aneurysm with tricuspid or bicuspid aortic valve. Eur. J. Histochem. 2014, 58, 2383. [CrossRef] [PubMed]

65. Tseng, V.; Ni, K.; Allawzi, A.; Prohaska, C.; Hernandez-Lagunas, L.; Elajaili, H.; Cali, V.; Midura, R.; Hascall, V.; Triggs-Raine, B.; et al. Extracellular Superoxide Dismutase Regulates Early Vascular Hyaluronan Remodeling in Hypoxic Pulmonary Hypertension. Sci. Rep. 2020, 10, 280. [CrossRef] [PubMed]

66. Marino, S.; Vooijs, M.; van Der Gulden, H.; Jonkers, J.; Berns, A. Induction of medulloblastomas in p53-null mutant mice by somatic inactivation of $\mathrm{Rb}$ in the external granular layer cells of the cerebellum. Genes Dev. 2000, 14, 994-1004.

67. Nauta, A.C.; Grova, M.; Montoro, D.T.; Zimmermann, A.; Tsai, M.; Gurtner, G.C.; Galli, S.J.; Longaker, M.T. Evidence that mast cells are not required for healing of splinted cutaneous excisional wounds in mice. PLoS ONE 2013, 8, e59167. [CrossRef] 